\title{
Potential application of grey oyster mushroom stems as Halal meat replacer in imitation chicken nuggets
}

\author{
${ }^{1,2}$ Husain, H. and ${ }^{2, *}$ Huda-Faujan, N., \\ ${ }^{1}$ Department of Agrotechnology and Bio-industry, Politeknik Nilai, 71760 Nilai, Negeri Sembilan, Malaysia. \\ ${ }^{2}$ Food Biotechnology Programme, Faculty of Science and Technology, Universiti Sains Islam Malaysia, \\ Bandar Baru Nilai, 71800 Nilai, Negeri Sembilan, Malaysia.
}

\author{
Article history: \\ Received: 22 August 2019 \\ Received in revised form: 2 \\ January 2020 \\ Accepted: 4 January 2020 \\ Available Online: 10 \\ February 2020
}

\section{Keywords:}

Imitation chicken nugget,

Grey oyster mushroom stems, Mushroom nugget,

Halal meat replacer,

Vegetarian nugget

DOI:

https://doi.org/10.26656/fr.2017.4(S1).S18

\begin{abstract}
Mushrooms have been consumed across the globe as cuisine's ingredients specifically for their Halal status, unique texture, and flavour. In this research, the potential of grey oyster mushroom stems (Pleurotus sajor-caju) as meat replacer was explored to evaluate the quality of imitation chicken nuggets (ICNs) production. Four formulations of ICNs were prepared with different percentage of grey oyster mushroom stems to chickpea flour were: A (60\%:10\%), B (55\%:15\%), C (50\%:20\%), and D (45\%:25\%). A commercial brand of chicken nuggets was chosen as a control experiment. All nuggets were evaluated for colour, texture, $\mathrm{pH}$, and water activity, as well as proximate composition. Results found that all ICNs were significantly higher $(P<0.05)$ in lightness, chewiness, springiness, water activity, and moisture than in control nugget. However, the $a^{*}$ value (green to red), protein, fat, and carbohydrate contents of all ICNs were significantly lower $(P<0.05)$ than in control nugget. These findings also suggested that grey oyster mushroom stems could be a great potential of an alternative Halal meat replacer in production of ICNs since the hardness, cohesiveness, and $\mathrm{pH}$ of all ICNs were found similar $(P>0.05)$ to control nugget.
\end{abstract}

\section{Introduction}

Mushrooms have been widely consumed by many people because of their flavour, soft texture, economic, ecological values, and medicinal properties (Sanchez, 2010). The unique flavour and tremendous benefits of nutrients in mushrooms have made them as the ingredient of gourmet cuisine. In Malaysia, the total demand for mushroom is projected to keep increasing to approximately 72,000 tonnes annually (Haimid et al., 2013). On the other hand, the rate of mushroom consumption is estimated to be 2.4 kilograms per person in 2020 (Ministry of Agriculture and Agro-Based Industry Malaysia, 2011). Furthermore, the addition of fruiting bodies or cap of mushroom in meat products has been successfully done (Wan Rosli et al., 2011; Arora et al., 2016; Wang et al., 2019). However, potential values of the stems were usually omitted and considered as food loss. Indeed, the food loss from mushroom production is high and create a problem in agro-industrial waste management (Barshteyn and Krupodorova, 2016).

The bright future for commercialising imitation meat products from mushroom was due to several factors such as the increment of meat price, scarce of animal protein in underdeveloped countries, strong demand for free- cholesterol food and low in saturated fat, as well as the quest for Halal meat-resemble food (Joshi and Kumar, 2015). Other than that, meat substitute products are currently primarily eaten by vegetarians and provide a big impact on health, religion, and ethical aspects (Hoek et al., 2004). Grumbles (2008) reported that amongst meat products, nugget was the only products accepted worldwide that has reached a high level of popularity compared to other meat. In fact, until now, the most common nuggets that can be found and available in the market is chicken nugget.

Imitation chicken nuggets (ICNs) comprise plantbased ingredients is also known as vegan nuggets. There are current tendencies of meat-based food companies in formulating new ingredients in chicken nuggets in order to fulfill the demands. High nutritional value, pleasant flavour, better taste and texture, as well as low in fat and cholesterol suit the quench of people on having good quality nuggets. In fact, high in fat content of five commercial chicken nuggets from different brands or manufacturers in Malaysia was reported by Lukman et al. (2009) and ranged from 18.14 to $25.00 \%$. By considering low in saturated fat and other benefits of mushroom stems in production of ICNs, however, it is also challenging since it may affect the physical 
properties of the original products. Previously, SharimaAbdullah et al. (2018) also reported that ICNs produced from chickpea flour and textured vegetable protein significantly reduced the fat content of the products than in commercial chicken nugget.

Imitation meat products that use fruiting bodies or cap of mushroom as Halal meat replacer could be achieved as mushroom has special characteristics of umami taste, excellence nutrients content as well as low in saturated fat and sodium (Mau, 2005). However, the application of mushroom stems in ICNs have not been explored in detail. Thus, the purpose of this study was to evaluate the physicochemical properties and proximate composition of ICNs produced from the different percentage of grey oyster mushroom stems in combination with chickpea flour which could be a further potential of a Halal meat replacer in ICNs.

\section{Materials and methods}

\subsection{Grey oyster mushroom stems preparation}

Collection of grey oyster mushroom stems were carried out from a mushroom farm (Nas Agro Farm) at Jenderam Hulu, Selangor, Malaysia. The samples were weighed before washing and rinsing using clean tap water. Next, the samples were air-dried using a sieve to drain the excess water until the original weight before washing. Then, the grey oyster mushroom stems were grounded in small portion for the ingredient in ICNs production.

\subsection{Nugget preparation}

In ICNs production, other ingredients such as chickpea flour, textured vegetable protein, corn starch, honey, salt, white pepper, chicken stock powder, isolated soy protein, wheat flour, and bread crumbs were purchased from a supermarket in Nilai, Negeri Sembilan, Malaysia. The four formulations of ICN were prepared as shown in Table 1.

Table 1. Formulation of four imitation chicken nuggets (ICNs)

\begin{tabular}{lcccc}
\hline Ingredient (\%) & $\mathrm{A}$ & $\mathrm{B}$ & $\mathrm{C}$ & $\mathrm{D}$ \\
\hline Grey oyster mushroom stems & 60 & 55 & 50 & 45 \\
Chickpea flour & 10 & 15 & 20 & 25 \\
Textured vegetable protein & 5 & 5 & 5 & 5 \\
Corn starch flour & 6 & 6 & 6 & 6 \\
Water & 15 & 15 & 15 & 15 \\
Honey & 1 & 1 & 1 & 1 \\
Salt & 1 & 1 & 1 & 1 \\
White pepper & 1 & 1 & 1 & 1 \\
Chicken stock powder & 1 & 1 & 1 & 1 \\
\hline
\end{tabular}

All ingredients were mixed and ground completely for approximately 10 mins and the batter was stored in the refrigerator at $4^{\circ} \mathrm{C}$ before coating process. Ingredients for coating were prepared by mixing $80 \%$ of soy milk and $20 \%$ wheat flour. The ICNs were shaped into the size of $4.0 \mathrm{~cm} \times 3.0 \mathrm{~cm} \times 0.5 \mathrm{~cm}$ and each was coated with the nugget coating before being dipped in breadcrumbs. All ICNs were then packed in a tight container and stored in $-18^{\circ} \mathrm{C}$ before analysis.

A commercial brand of nugget that used as a control in this study contains chicken, corn starch, breadcrumb (contains wheat), vegetable protein (contains soy), spices, salt, chicken seasoning, and monosodium glutamate as stated on the packaging.

\subsection{Cooking procedure}

All frozen nuggets were thawed at $4{ }^{\circ} \mathrm{C}$ for an hour before deep frying in the pan for three minutes in $50 \mathrm{~mL}$ palm oil.

\subsection{Physicochemical analysis}

\subsubsection{Colour}

Determination of colour of all fried nuggets was measured using colorimeter (LabScan ${ }^{\circledR} \quad$ XE Spectrophotometer Model, HunterLab) based on $L^{*} a^{*} b^{*}$ colour scale system. $L^{*}$ value represents lightness/ darkness, $a^{*}$ value represent redness/greenness, and $b^{*}$ value represents yellowness/ blueness. Approximately, $15 \mathrm{~g}$ of nugget sample was placed within a plastic Petri dish with the lid on and the colour was measured according to the manufacturer's instruction.

\subsubsection{Texture profile analysis}

Texture of all fried nuggets was measured using texture analyser (TA-XT Plus Model, Stable Micro System) according to the manufacturer's instruction. All fried nuggets were cut into cube sized $(1 \mathrm{~cm} \times 1 \mathrm{~cm} \times$ $0.5 \mathrm{~cm}$ ) and was placed into a $36 \mathrm{~mm}$ diameter cylindrical probe 75 (P.75) during analysis. The $4 \mathrm{~mm}$ probe connected to the texture analyser was used for compression analysis of hardness, chewiness, springiness, and cohesiveness.

\section{$2.4 .3 \mathrm{pH}$}

The $\mathrm{pH}$ of all raw nuggets was measured using a digital $\mathrm{pH}$ meter (Model Aqua Lab). Prior to analysis, $10 \mathrm{~g}$ of each nugget was weighed and added with $50 \mathrm{~mL}$ of deionised water. Then, the samples were homogenised using a homogeniser (Model Stomacher 400 Circulator) for 60 seconds before measuring the $\mathrm{pH}$ directly using the digital $\mathrm{pH}$ meter.

\subsubsection{Water activity}

The water activity $\left(\mathrm{A}_{\mathrm{w}}\right)$ of all raw nuggets was 
determined at $25^{\circ} \mathrm{C}$ using an Aqualab Series 4TE water activity meter (Decagon, Pullman, WA, USA) according to manufacturer's instruction.

\subsection{Proximate analysis}

Analysis of moisture, crude protein, fat, and ash were carried out only for all fried nuggets according to the methods of the Association of Official Analytical Chemists (AOAC, 2005).

\subsubsection{Moisture}

The moisture content of all fried nugget samples was determined using mechanical moisture analyser (MX-50, AandD Company, Limited). The percentage of moisture content was measured by calculating the difference of wet weight and dry weight of the sample. Before analysis, each nugget sample was weighed approximately $2.0 \mathrm{~g}$ and heated at $200^{\circ} \mathrm{C}$ for few minutes (for standard drying) to maintain the temperature throughout the whole analysis.

\subsubsection{Ash}

The total ash content of all fried nugget samples was determined according to AOAC (2005) Method 920.153 using conventional dry-ashing. The percentage of crude ash was calculated using the following equation.

Crude ash (\%) dry basis $=\left[\mathrm{W}_{1} / \mathrm{W}_{2}\right] \times 100$

Where $\mathrm{W}_{1}=$ weight after ashing; $\mathrm{W}_{2}=$ weight before ashing.

\subsubsection{Protein}

The nitrogen content of all fried nugget samples was analysed using Kjeldahl method (AOAC, 2005) Method 928.08. Measurement of crude protein percentage was expressed as the total of nitrogen percentage and multiplied by a factor of 6.25 (nitrogen-protein conversion factor for meat and grain sample).

Crude protein $(\%)=$ Nitrogen $(\%)$ in samples x 6.25

\subsubsection{Fat}

Fat analysis was automatically conducted using Automatic Soxhlet extraction method (Soxhterm extractor, Gerhardt). The fat content of all fried nugget samples was calculated as follows equation.

Fat $(\%)=\left[\left(\mathrm{W}_{1}-\mathrm{W}_{2}\right) / \mathrm{W}_{0}\right] \times 100$

Where $\mathrm{W}_{0}=$ weight of nugget sample after treatment; $\mathrm{W}_{1}=$ total weight of extraction beaker with boiling stones and extracted fats; $\mathrm{W}_{2}=$ total weight of extraction beaker and boiling stones.

\subsubsection{Carbohydrate}

Carbohydrate content of all fried nugget samples was measured by totalling up the percentage of moisture, ash, protein, and fat, followed by deducting the result from $100 \%$. The carbohydrate content was determined as available carbohydrate and was calculated using the following equation.

Carbohydrate $(\%)=100-[$ moisture $(\%)+$ ash $(\%)+$ protein $(\%)+$ fat $(\%)]$

\subsection{Statistical analysis}

All data were analysed using one-way analysis of variance (ANOVA), followed by Tukey HSD Test to compare the means between samples. Data was analysed using IBM SPSS (Statistical Package for the Social Science) software version 21, and the statistical significance was established at $(P<0.05)$. All experiments were replicated twice.

\section{Results and discussion}

\subsection{Physicochemical properties of imitation chicken} nuggets

The physical characteristics of all fried nuggets include internal nugget colour and texture are shown in Table 2. From the table, results obtained that internal

Table 2. Physical properties of four fried ICNs compared to fried control nugget

\begin{tabular}{cccccc}
\hline Nugget sample & Control & A & B & C & D \\
\hline$L^{*}$ & $54.72^{\mathrm{a}}$ & $59.33^{\mathrm{ab}}$ & $58.42^{\mathrm{abc}}$ & $57.24^{\mathrm{bcd}}$ & $56.33^{\mathrm{cd}}$ \\
$a^{*}$ & $10.23^{\mathrm{a}}$ & $9.59^{\mathrm{abc}}$ & $8.99^{\mathrm{bc}}$ & $9.51^{\mathrm{abc}}$ & $9.11^{\mathrm{bc}}$ \\
$b^{*}$ & $29.20^{\mathrm{a}}$ & $29.53^{\mathrm{a}}$ & $29.16^{\mathrm{a}}$ & $30.02^{\mathrm{a}}$ & $29.96^{\mathrm{a}}$ \\
Hardness (N) & $6.14^{\mathrm{a}}$ & $6.12^{\mathrm{a}}$ & $5.88^{\mathrm{a}}$ & $5.81^{\mathrm{a}}$ & $5.62^{\mathrm{b}}$ \\
Chewiness (N/cm) & $2.05^{\mathrm{b}}$ & $3.06^{\mathrm{a}}$ & $2.49^{\mathrm{a}}$ & $2.38^{\mathrm{a}}$ & $2.38^{\mathrm{a}}$ \\
Springiness (cm) & $0.76^{\mathrm{b}}$ & $0.94^{\mathrm{a}}$ & $0.92^{\mathrm{a}}$ & $0.90^{\mathrm{a}}$ & $0.88^{\mathrm{a}}$ \\
Cohesiveness (ratio) & $0.45^{\mathrm{ab}}$ & $0.53^{\mathrm{a}}$ & $0.49^{\mathrm{ab}}$ & $0.46^{\mathrm{ab}}$ & $0.38^{\mathrm{b}}$ \\
\hline
\end{tabular}

Means in the same row with different lowercase letters indicate significant differences $(P<0.05)$ between formulations of ICNs and control nugget. Control=commercial chicken nugget; $\mathrm{A}=60 \%$ grey oyster mushroom stems and $10 \%$ chickpea flour; $\mathrm{B}=55 \%$ grey oyster mushroom stems and $15 \%$ chickpea flour; $\mathrm{C}=50 \%$ grey oyster mushroom stems and $20 \%$ chickpea flour; and $\mathrm{D}=45 \%$ grey oyster mushroom stems and $25 \%$ chickpea flour. 
nugget colour of all ICNs was significantly higher $(P<0.05)$ than in control nugget. The lighter of internal nugget colour in ascending order $\left(L^{*}\right)$ (darkness to whiteness) was obtained in ICN D (56.33), ICN C (57.24), ICN B (58.42), and ICN A (59.33) while control nugget showed the darkest of internal colour (54.72). Previously, Wan Rosli et al. (2011) reported that a decreasing amount of grey oyster mushroom in chicken patties produced lighter colour. However, in this study, the combination of grayish-white colour of grey oyster mushroom stems and yellowish colour of chickpea flour in ICN formulations could explain why $L^{*}$ value of ICNs decreased with decreasing amount of grey oyster mushroom stems to chickpea flour. The lowest $(P<0.05)$ $L^{*}$ value in internal control nugget colour (54.72) might be mainly contributed from the yellowness of breadcrumb which was the third major ingredient of nugget as labelled.

The ranged of $a^{*}$ value (green to red) of all $\mathrm{ICN}_{\mathrm{S}}$ was lower $(P<0.05)$ than in control nugget and the ranged were between 8.99 and 9.59. The value of $a^{*}$ in control nugget was the highest (10.23) while ICN A obtained the highest value (9.59) of $a^{*}$ among all ICNs. The $a^{*}$ value of all ICNs in ascending order were ICN B (8.99), ICN D (9.11), ICN C (9.51), and ICN A (9.59). The increasing amount of grey oyster mushroom up to $50 \%$ in chicken patties decreased $a^{*}$ value but was not significantly $(P>0.05)$ differed to control patties (Wan Rosli et al., 2011). In this study, $a^{*}$ value in all ICNs did not show a consistent pattern and might be due to the combination of grayish-white colour of grey oyster mushroom stems and yellowish colour of chickpea flour in ICN formulations.

The $b^{*}$ value (blue to yellow) of all nuggets ranged between 29.16 and 30.02. The value of $b^{*}$ in ascending order were ICN B (29.16), control nugget (29.20), ICN A (29.53), ICN D (29.96), and ICN C (30.02). Interestingly, the value of $b^{*}$ in control nugget and all ICNs found similar to each other $(P>0.05)$. The yellow colour of control nugget might be mainly due to breadcrumb and vegetable protein (soy) content in the product. According to Sharima-Abdullah et al. (2018), the yellow colour of ICNs which contain 10 up to $30 \%$ of chickpea flour increased from 27.46 to 40.26 . The yellow colour of a food product mainly influences consumer preference (Arifin et al., 2019; SharimaAbdullah et al., 2018).

The results of the nugget's texture are also shown in Table 2. It is found that the hardness of control nugget was the highest $(6.14 \mathrm{~N})(P>0.05)$ while the hardness of ICNs samples in ascending order was ICN D $(5.62 \mathrm{~N})$, ICN C $(5.81 \mathrm{~N})$, ICN B $(5.88 \mathrm{~N})$, and ICN A $(6.12 \mathrm{~N})$.
Control nugget which contained chicken meat as the main ingredient contributed to the hardness of the product. In this study, the hardness of ICNs decreased consistently with the decreasing amount of grey oyster mushroom stems and the increasing amount of chickpea flour. Indeed, the increasing amount of chickpea flour in ICNs (Sharima-Abdullah et al., 2018) and beef sausages (Verma et al., 1984) provide softer texture in both products. However, the addition of grey oyster mushroom up to $50 \%$ in chicken patties by itself obtained softer texture $(109.8 \mathrm{~N})$ compared to the addition of $25 \%$ grey oyster mushroom in chicken patties (129.4 N) (Wan Rosli et al., 2011). This explained why decreasing amount of grey oyster mushroom stems in combination with the increasing amount of chickpea flour in ICNs consistently produced a softer texture of ICNs.

Chewiness, springiness, and cohesiveness are also important attributes in evaluating nugget's texture. Chewiness is defined as the energy required to chew meat product (Sarıçoban et al., 2009) while springiness was defined as how well a product physically springs back to the initial condition during the first compression (Yılmaz and Dağlığlu, 2003). According to Sarıçoban et al. (2009) cohesiveness is related to the extent to which food can be deformed before it ruptures. In this study, it was found that chewiness and springiness of control nugget were significantly lower $(P<0.05)$ than in all ICNs. The chewiness and springiness of control nugget were $2.05 \mathrm{~N} / \mathrm{cm}$ and $0.76 \mathrm{~cm}$, respectively. However, the ranged of chewiness and springiness of all ICNs were between 2.38 and $3.06 \mathrm{~N} / \mathrm{cm}$, and between 0.88 and $0.94 \mathrm{~cm}$, respectively. Among all ICNs, the ICN A (60\% grey oyster mushroom stems and $10 \%$ chickpea flour) found the chewiest $(3.06 \mathrm{~N} / \mathrm{cm})$, and most springy $(0.94 \mathrm{~cm})$. The chewiness of all ICNs was consistently decreased when the chickpea flour in the ICNs formulation increased (grey oyster mushroom stems decreased) and was in line with a study by Sharima-Abdullah et al. (2018).

Cohesiveness of control nugget was also the lowest (0.45) $(P>0.05)$ than in all ICNs and the highest cohesiveness was also found in ICN A (0.53). The cohesiveness of all ICNs in descending order was ICN A (0.53), ICN B (0.49), ICN D (0.48), and ICN C (0.46). According to Sharima-Abdullah et al. (2018), an increasing amount of chickpea flour with a decreasing amount of textured vegetable protein in ICNs consistently decreases the cohesiveness of the products. However, Wan Rosli et al. (2011) found that increasing amount of grey oyster mushroom decreased cohesiveness of chicken patty. Indeed, the lower values of chewiness, springiness, and cohesiveness of control nugget in this 
study compared to all ICNs could be due to the application of breadcrumb as the third major of its ingredient.

The chemical properties of raw nuggets were done in order to measure the $\mathrm{pH}$ and water activity of the products. From Table 3, the highest $\mathrm{pH}$ was found in ICN C (pH 6.60) $(P>0.05)$. The $\mathrm{pH}$ range of all nuggets obtained slightly acidic from $\mathrm{pH} 6.50$ to $\mathrm{pH} 6.60$. The $\mathrm{pH}$ of nuggets in ascending order (less acidic) was ICN A (6.50), ICN D (6.52), B (6.53), control nugget (6.57), and $\mathrm{C}$ (6.60). According to Mbougueng et al. (2015) $\mathrm{pH}$ of raw beef patties formulated with different starch types ranged between $\mathrm{pH} 5.78$ and $\mathrm{pH}$ 5.80. However, less acidic $\mathrm{pH}$ in ICNs in this study could be due to the chickpea flour ingredient as $\mathrm{pH}$ of chickpea flour was $\mathrm{pH}$ 6.93 (Verma et al., 2012). In fact, $\mathrm{pH}$ value in meat product is an important chemical factor because it will affect shelf-life, colour, water holding capacity, and

Table 3. Chemical properties of ICNs compared to control nugget

\begin{tabular}{cccccc}
\hline Nugget samples & Control & $\mathrm{A}$ & $\mathrm{B}$ & $\mathrm{C}$ & $\mathrm{D}$ \\
\hline $\mathrm{pH}$ value & $6.57^{\mathrm{a}}$ & $6.50^{\mathrm{a}}$ & $6.53^{\mathrm{a}}$ & $6.60^{\mathrm{a}}$ & $6.52^{\mathrm{a}}$ \\
Water activity $\left(\mathrm{A}_{\mathrm{w}}\right)$ & $0.94^{\mathrm{c}}$ & $0.96^{\mathrm{a}}$ & $0.96^{\mathrm{a}}$ & $0.96^{\mathrm{a}}$ & $0.95^{\mathrm{b}}$ \\
\hline
\end{tabular}

Means in the same row with different lowercase letters indicate significant differences $(P<0.05)$ between formulations of ICNs and control nugget. Control $=$ commercial chicken nugget; $A=60 \%$ grey oyster mushroom stems and $10 \%$ chickpea flour; $\mathrm{B}=55 \%$ grey oyster mushroom stems and $15 \%$ chickpea flour; $C=50 \%$ grey oyster mushroom stems and 20\% chickpea flour; and $\mathrm{D}=45 \%$ grey oyster mushroom stems and $25 \%$ chickpea flour.

texture of meat products (Abd-El-Qader, 2003). Thus, this study could be used as an indicator for prediction of the shelf life of all ICNs that might be similar to control nugget for further analysis.

The water activity of raw control nugget was the lowest $\left(\mathrm{A}_{\mathrm{w}}=0.94\right)$ and was significantly differed $(P<0.05)$ from all raw ICNs. The water activity of all ICNs was found significantly higher $(P<0.05)$ than in control nugget and ranged between 0.95 and 0.96 .
According to Deb et al. (2018), the water activity of fresh pearl oyster mushroom (Pleurotus ostreatus) was 0.98 . Furthermore, in this study, the amount of corn starch flour in all ICN formulations was only $6 \%$ (fourth major ingredient) compared to control nugget that used corn starch as a second major ingredient (probably high in percentage than in this experiment). It is known that corn starch could function as a binder as well as the water-binding capacity of free water in the food system and at the same time reduce water activity (Devadason et al., 2010). This could explain why water activity of control nugget was significantly lower $(P<0.05)$ than in all ICNs.

\subsection{Proximate composition of imitation fried chicken nuggets}

The moisture, ash, protein, fat, and carbohydrate contents of fried nuggets are shown in Table 4. It is found that control nugget was significantly higher $(P<0.05)$ percentage in protein, fat, and carbohydrate content than in all ICNs. However, moisture content of control nugget was significantly lower $(P<0.05)$ than in all ICNs. From Table 4, the moisture content of all fried ICNs ranged from 55.42 to $62.90 \%$ compared to $43.33 \%$ in fried control nugget. The moisture contents of ICNs in ascending order were ICN C (55.22\%), ICN D (55.42\%), ICN B (57.56\%), and ICN A (62.90\%). The high values of moisture in ICNs might be related to the high content of moisture in grey oyster mushroom stems compared to in the mushroom cap. Previously, Oluwafemi et al, (2016) reported that moisture of stalk or stem of edible mushroom Pleurotus ostreatus (pearl oyster mushroom) was $6.30 \%$ higher than in the cap part $(3.50 \%)$ of the mushroom. This could explain why the moisture content of all fried ICNs in this study was significantly higher $(P<0.05)$ than in control nugget.

Ash of nuggets was determined to measure the total amount of minerals. The fried ICN D which was formulated from $45 \%$ grey oyster mushroom stems and $25 \%$ chickpea flour were found to have the highest $(3.03 \%)(P<0.05)$ ash content compared to all fried

Table 4. Proximate composition of four ICNs compared to control nugget

\begin{tabular}{cccccc}
\hline \multirow{2}{*}{$\begin{array}{c}\text { Proximate } \\
\text { composition (\%) }\end{array}$} & \multicolumn{5}{c}{ Nugget samples } \\
\cline { 2 - 6 } & Control & A & B & C & D \\
\hline Moisture & $43.33^{\mathrm{c}}$ & $62.90^{\mathrm{a}}$ & $57.56^{\mathrm{b}}$ & $55.22^{\mathrm{b}}$ & $55.42^{\mathrm{b}}$ \\
Ash & $2.95^{\mathrm{b}}$ & $2.96^{\mathrm{b}}$ & $2.95^{\mathrm{b}}$ & $2.93^{\mathrm{b}}$ & $3.03^{\mathrm{a}}$ \\
Protein & $9.84^{\mathrm{a}}$ & $6.99^{\mathrm{b}}$ & $7.78^{\mathrm{ab}}$ & $8.63^{\mathrm{ab}}$ & $8.74^{\mathrm{ab}}$ \\
Fat & $1.30^{\mathrm{a}}$ & $0.62^{\mathrm{b}}$ & $0.60^{\mathrm{b}}$ & $0.52^{\mathrm{b}}$ & $0.47^{\mathrm{b}}$ \\
Carbohydrate & $42.59^{\mathrm{a}}$ & $26.52^{\mathrm{b}}$ & $31.12^{\mathrm{ab}}$ & $32.71^{\mathrm{ab}}$ & $32.34^{\mathrm{ab}}$ \\
\hline
\end{tabular}

Means in the same row with different lowercase letters indicate significant differences $(P<0.05)$ between formulations of ICNs and control nugget. Control=commercial chicken nugget; $A=60 \%$ grey oyster mushroom stems and $10 \%$ chickpea flour; $B=55 \%$ grey oyster mushroom stems and $15 \%$ chickpea flour; $C=50 \%$ grey oyster mushroom stems and $20 \%$ chickpea flour; and $\mathrm{D}=45 \%$ grey oyster mushroom stems and $25 \%$ chickpea flour. 
nuggets (Table 4). Ash content of ICN A to ICN C found to be similar (2.93 to $2.96 \%$ ) to each other. In fact, the ash content of chickpea flour ranged between 3.00 and 3.20\% (Aguilar et al., 2015; Ghribi et al., 2015) while ash content of pearl oyster mushroom stems' (Pleurotus ostreatus) was 5.30\% (Oluwafemi et al., 2016). This could explain why the ash content of fried ICN D in this study was found the highest $(P<0.05)$ among all fried nuggets.

Protein content of fried control nugget $(9.84 \%)$ was significantly higher $(P<0.05)$ than in all fried ICNs followed by a decline of ICN D (8.74\%), ICN C (8.63\%), ICN B (7.78\%), and ICN A (6.99\%) (Table 4). Interestingly, the decreasing amount of chickpea flour with the increasing amount of grey oyster mushroom stems in ICN formulations were consistently decreased $(P<0.05)$ the protein content of ICNs. Previously, Ghribi et al. (2015) reported that the protein content of chickpea flour was 20.3\% (Desi cultivar), and 24.5\% (Kabuli cultivar). Indeed, the protein content of chickpea flour used in this study was $23.0 \%$ as labelled in the packaging. Furthermore, the protein content of Pleurotus ostreatus stems' was $21.00 \%$ (Oluwafemi et al., 2016) and seemed almost the same to the protein content in chickpea flour. Thus, the decreasing amount of chickpea flour with the increasing amount of grey oyster mushroom stems in ICN formulations necessarily decreased protein content of ICNs. Protein content in fried control nugget is mainly contributed by chicken meat and most probably was also contributed by vegetable protein (contains soy) as labelled as the third major ingredient in the packaging.

Fat content is one of the important nutrients to be claimed that the ICNs were healthier than in control nugget due to ICN did not contain saturated fats and cholesterol since ICNs were produced from a plant-based source. Besides, ICNs can promote Halal meat replacer because plant-based products did not contain animal source which is very strictly concerned about Halal animal and Syariah compliance slaughtering process. As expected, the highest $(P<0.05)$ fat content was observed in control nugget $(1.30 \%)$, followed by a decline of ICN A $(0.62 \%)$, ICN B $(0.60 \%)$, ICN C $(0.52 \%)$, and ICN D $(0.47 \%)$ (Table 4$)$. The fat content of fried ICNs was consistently decreased $(P<0.05)$ with the decreasing percentage of chickpea flour to grey oyster mushroom stems. In this study, the fat content of chickpea flour used was $4.1 \%$ as mentioned on the packaging. The fat content of mushroom stems of Pleurotus ostreatus was $1.50 \%$ (Oluwafemi et al., 2016). In fact, when the ICNs (from ICN A to ICN D) were fried, the amylose content in chickpea flour increased and absorbed less oil. According to Mohamed et al. (1998), oil absorption was negatively correlated with amylose content in starch. This could explain why the fat content in fried ICNs increased when the percentage of chickpea flour decreased in ICN formulations. This finding was also in line with a previous study done on ICNs with chickpea flour in combination with textured vegetable protein (Sharima-Abdullah et al., 2018).

Most of the carbohydrate content in nuggets was probably due to the nugget containing starch. Surprisingly, this study found that fried control nugget contained the highest $(P<0.05)$ content of carbohydrate $(42.59 \%)$ than in all fried ICNs. The carbohydrate content in all fried ICNs in ascending order was ICN A (26.52\%), ICN B (31.12\%) ICN D (32.34\%), and ICN C (32.71). According to Crisan and Sands (1978), carbohydrates are high in mushrooms stems as the glycogen is concentrated in the stem together with pentoses, hexoses, and other polymeric carbohydrates. In fact, Oluwafemi et al. (2016) proved that carbohydrate content in Pleurotus ostreatus stem was higher (61.80\%) than in its cap $(52.90 \%)$. The highest content of carbohydrate in control nugget was probably due to the content of corn starch and breadcrumb containing wheat as the second and third major ingredient, respectively.

\section{Conclusion}

This study concluded that physicochemical properties of ICNs produced from grey oyster mushroom stems and chickpea flour did not significantly $(P>0.05)$ changed the hardness, cohesiveness, and $\mathrm{pH}$ of nuggets compared to control nugget. However, all ICNs were significantly higher $(P<0.05)$ in moisture but were significantly lower $(P<0.05)$ in protein, fat, and carbohydrate. Thus, it is suggested that the ICNs in this study which formulated with grey oyster mushroom stems as a major ingredient could be a great potential of an alternative Halal meat replacer in production of chicken nugget since the texture is comparable with control nugget. However, consumer acceptance of these ICNs will be studied to evaluate the degree of these products' preference.

\section{Acknowledgements}

The author acknowledges the financial support provided by USIM and Ministry of Education, Malaysia for the assistance and scholarship funding. The author also extends their thanks to Mr Nabil Sanusi from Nas Agro Farm, Jenderam Hulu, Sepang, Selangor, Malaysia to provide grey oyster mushroom stems for this study. Furthermore, thanks also to Universiti Sains Islam Malaysia for providing the laboratory facility for conducting the present study. Special appreciations to 
Mrs Rina Abdul Wahap, Mrs Norhafiza Abdul Ghafar and Mrs Normah Haron for their assistance.

\section{References}

Abd-El-Qader, M.F. (2003). Quality improvement of chicken frozen burger formulated with some spices or their volatile oils. Egypt: Cairo University, MSc thesis.

Aguilar, N., Albanell, E., Minarro, B. and Capellas, M. (2015). Chickpea and tiger nut flours as alternatives to emulsifier and shortening in gluten-free bread. LWT - Food Science and Technology, 62(1), 225232. https://doi.org/10.1016/j.lwt.2014.12.045

AOAC (Association of Official Analytical Chemists). (2005). Official Methods of Analysis (18 ${ }^{\text {th }}$ Edition). Washington: Washington, D.C.

Arora, B., Kamal, S. and Sharma, V.P. (2016). Effect of binding agents on quality characteristics of mushroom based sausage analogue. Journal of Food Processing and Preservation, 41(5), e13134. https:// doi.org/10.1111/jfpp.13134

Arifin, N., Siti Nur Izyan, M.A. and Huda-Faujan, N. (2019). Physical properties and consumer acceptability of basic muffin made from pumpkin puree as butter replacer. Food Research, 3(6), 840845. https://doi.org/10.26656/fr.2017.3(6).090

Barshteyn, V. and Krupodorova, T. (2016). Utilization of agro-industrial waste by higher mushrooms: modern view and trends. Journal of Microbiology, Biotechnology and Food Sciences, 5(6), 563-577. $\mathrm{https//doi.org/10.15414/jmbfs.2016.5.6.563-577}$

Crisan, E.V. and Sands, S.A. (1978). Nutritional Value of Edible Mushrooms in the Biology and Cultivation of Edible Mushrooms, p. 137-168. USA: New York Academic Press. https://doi.org/10.1016/B978-0-12168050-3.50012-8

Deb, U., Jagannath, A., Anilakumar, K.R., Mallesha, and Chatterjee, S. (2018). Nutritional studies and antioxidant profile of pickled oyster mushrooms of northeast India. Defence Life Science Journal, 3(1), 64-70. https://doi.org/10.14429/dlsj.3.12157

Devadason, I.P., Anjaneyulu, A.S.R. and Babji, Y. (2010). Effect of different binders on the physicochemical, textural, histological, and sensory qualities of retort pouched buffalo meat nuggets. Journal of Food Science, 75(1), S31-S35. https:// doi.org/10.1111/j.1750-3841.2009.01399.x

Ghribi, A.M., Maklouf, I., Blecker, C., Attia, H. and Besbes, S. (2015). Nutritional and compositional study of Desi and Kabuli chickpea (Cicer arietinum L.) flours from Tunisian cultivars. Advanced of Food Technology Nutritional Science Open Journal, 1(2):
38- 47. https://doi.org/10.17140/AFTNSOJ-1-107

Grumbles, S.L. (2008). Optimization of ingredient and process parameters for chicken nuggets. California: Oklahoma State University, MSc Thesis.

Haimid, M.T., Rahim, H., and Dardak, R.A. (2013). Understanding the mushroom industry and its marketing strategies for fresh produce in Malaysia. Economic and Technology Management Review, 8, 27-37.

Hoek, A.C., Luning, P.A., Stafleu, A. and de Graaf, C. (2004). Food-related lifestyle and health attitudes of Dutch vegetarians, non-vegetarian consumers of meat substitutes, and meat consumers. Appetite, 42 (3), 265-272. https://doi.org/10.1016/ j.appet.2003.12.003

Joshi, V.K. and Kumar, S. (2015). Meat analogues: plant based alternatives to meat products -a review. International Journal of Food and Fermentation Technology, 5(2), 107-119. https:// doi.org/10.5958/2277-9396.2016.00001.5

Lukman, I., Huda, N. and Ismail, N. (2009). Physicochemical and sensory properties of commercial chicken nuggets. Asian Journal of Food and Agro-Industry, 2(2), 171-180.

Mau, J. (2005). The umami taste of edible and medicinal mushrooms. International Journal of Medicinal Mushrooms, 7(1/2), 119-126. http://doi.org/10.1615/ IntJMedMushr.v7.i12.120

Mbougueng, P.D., Tenin, D., Tchiégang, C. and Scher, J. (2015). Effect of starch type on the physicochemical and textural properties of beef patties formulated with local spices. American Journal of Food Science and Technology, 3(2), 33-39.

Ministry of Agriculture and Agro-Based Industry Malaysia. (2011). Bab 7: Memacu Pertumbuhan Pertanian Bernilai Tinggi. In Dasar Agromakanan Negara (2011 - 2020) (DAN), p. 96. Kuala Lumpur: Percetakan Watan Sdn. Bhd.

Mohamed, S., Abd Hamid, N. and Abd Hamid, M. (1998). Food components affecting the oil absorption and crispness of fried batter. Journal of the Science of Food and Agriculture, 78(1), 39-45. https:// doi.org/10.1002/(SICI)1097-0010(199809)

78:1<39::AID-JSFA82>3.0.CO;2-G

Oluwafemi, G.I., Seidu, K.T. and Fagbemi, T.N. (2016). Chemical composition, functional properties and protein fractionation of edible oyster mushroom (Pleurotus ostreatus)., Annals. Food Science and Technology, 179(1), 218-223.

Sanchez, C. (2010). Cultivation of Pleurotus ostreatus and other edible mushrooms. Applied Microbiology and Biotechnology, 85(5), 1321-1337. https:// 
doi.org/0.1007/s00253-009-2343-7

Sarıçoban, C., Yılmaz, M.T. and Karakaya M. (2009). Response surface methodology study on the optimisation of effects of fat, wheat bran and salt on chemical, textural and sensory properties of patties. Meat Science, 83(4), 610-619. https:// doi.org/10.1016/j.meatsci.2009.07.010

Sharima-Abdullah, N., Hassan, C.Z., Arifin, N. and Huda-Faujan, N. (2018). Physicochemical properties and consumer preference of imitation chicken nuggets produced from chickpea flour and textured vegetable protein. International Food Research Journal, 25(3), 1016-1025.

Verma, A. K., Banarjee, R. and Sharma, B.D. (2012). Quality of low fat chicken nuggets: effect of sodium chloride replacement and added chickpea (Cicer arietinum L.) hull flour. Asian-Australasian Journal of Animal Science, 25(2), 291-298. https:// doi.org/10.5713/ajas.2011.11263

Verma, M.M., Ledward, D.A. and Lawrie, R.A. (1984). Utilization of chickpea flour in sausage. Meat Science, 11(2), 109-121. https:// doi.org/10.1016/0309-1740(84)90009-3

Wan Rosli, W.I., Solihah, M.A., Aishah, M., Nik Fakurudin, N.A. and Mohsin, S.S.J. (2011). Colour, textural properties, cooking characteristics and fibre content of chicken patty added with oyster mushroom (Pleurotus sajor-caju). International Food Research Journal, 18(2), 621-627.

Wang, L., Guo, H., Liu, X., Jiang, G., Li, C., Li, X. and Li, Y. (2019). Roles of Lentinula edodes as the pork lean meat replacer in production of the sausage. Meat Science, 156, 44-51. https://doi.org/10.1016/ j.meatsci.2019.05.016

Yılmaz, I. and Dağlioğlu, O. (2003). The effect of replacing fat with oat bran on fatty acid composition and physicochemical properties of meatballs. Meat Science, 65(2): 819-823. https://doi.org/10.1016/ S0309-1740(02)00286-3 